\begin{tabular}{|c|c|c|c|c|c|}
\hline $\begin{array}{l}\text { Author, date, } \\
\text { and country }\end{array}$ & Patient group & $\begin{array}{l}\text { Study type } \\
\text { (level of } \\
\text { evidence) }\end{array}$ & Outcomes & Key results & Study weaknesses \\
\hline $\begin{array}{l}\text { Holdsworth } e t \\
\text { al, 1987, } \\
\text { UK }^{1}\end{array}$ & $\begin{array}{l}80 \text { adult patients with radial } \\
\text { head fractures } \\
\text { Aspiration, bupivicaine injection, } \\
\text { and early mobilisation } v \text { early } \\
\text { mobilisation alone }\end{array}$ & PRCT & $\begin{array}{l}\text { Range of movement } \\
\text { Grip strength } \\
\text { Aspiration success } \\
\text { Pain after aspiration }\end{array}$ & $\begin{array}{l}\text { No difference } \\
\text { No results reported } \\
3 / 41 \text { could not be aspirated } \\
\text { Improvement reported }\end{array}$ & $\begin{array}{l}\text { Unblinded. Randomisation method not } \\
\text { explicit. } 14 \text { patients lost to follow up } \\
\text { Measurements were taken at } 2,6,12 \text {, } \\
26 \text {, and } 52 \text { weeks; it is unclear which } \\
\text { period the results presented apply to. } \\
\text { Grip strength data are not reported }\end{array}$ \\
\hline $\begin{array}{l}\text { Dooley and } \\
\text { Angus, } \\
1991, \mathrm{UK}^{2}\end{array}$ & $\begin{array}{l}28 \text { adult patients with type } 1 \text { or } 2 \\
\text { radial head fractures } \\
\text { Aspiration (13) } v \text { no aspiration }\end{array}$ & PRCT & Range of movement & $\begin{array}{l}\text { Better immediately after } \\
\text { aspiration and at } 3 \text { and } 6 \\
\text { months } \\
\text { Better immediately after } \\
\text { aspiration and at } 3 \text { and } 6 \\
\text { months }\end{array}$ & $\begin{array}{l}\text { Unblinded. Randomisation method not } \\
\text { explicit. Small numbers. No } \\
\text { statistical analysis } \\
\text { Non-standard methods for } \\
\text { measurement of outcomes }\end{array}$ \\
\hline
\end{tabular}

PRCT = prospective randomised controlled trial.

The role of therapeutic needle aspiration in radial head fractures

Report by Simon Carley, Specialist Registrar Search checked by Rob Birkenshaw, Specialist Registrar

\section{Clinical scenario}

A 17 year old female presents to the emergency department after a fall onto her right forearm. She complains of elbow pain and has a limited range of movement of that joint. Radiography reveals a moderate elbow effusion and an undisplaced fracture of the radial head (Manson type 1). You wonder whether aspirating the joint is worthwhile.

Three part question

In [patients with traumatic elbow effusions] is [aspiration of the joint better than conservative treatment] in [reducing symptoms and time to healing]?

Search strategy

Medline 1966 to $3 / 99$ using the OVID interface. [ exp elbow OR exp elbow joint OR elbow\$.mp OR exp radius OR exp radius fractures OR radial head\$.mp\} AND \{exp aspira- tion OR aspiration.mp OR aspirate $\$ . m p\}$ ] LIMIT to human and english language.

\section{Search outcome}

Forty seven papers were found of which 45 were irrelevant to the study question or of insufficient quality for inclusion; the remaining papers are shown in table 3.

\section{Comment}

The studies relevant to this question are very poor in design and execution. A properly designed prospective randomised controlled trial looking at pain, mobility, time to healing, and harm (infection rate) is necessary to investigate this further.

\section{Clinical bottom line}

While aspiration may benefit patients with traumatic elbow effusions the evidence is too poor to recommend it as a routine procedure.

1 Holdsworth BJ, Clements DA, Rothwell PN. Fractures of the radial head-the benefit of aspiration: a prospective controlled trial. Injury 1987;18:44-7.

2 Dooley JF, Angus PD. The importance of elbow aspiration when treating radial head fractures. Arch Emerg Med 1991; 8:117-21.
In [adults with a clinical diagnosis of olecranon bursitis] does [diagnostic aspiration of the bursa] lead to [better diagnosis and outcome].
Search strategy

Medline 1966 to $3 / 99$ using the OVID interface. ( $\{$ exp elbow OR exp elbow joint OR olecranon\$.mp\} AND \{bursa \$.mp OR exp bursa, synovial OR exp bursitis OR bursitis.mp\}] OR [sepsi\$ AND \{bursa \$.mp OR exp bursa, synovial OR exp bursitis OR bursitis.mp\}]) LIMIT to human and english language.

\section{Search outcome}

Two hundred and nineteen papers were found of which 200 were irrelevant and 17 of insufficient quality for inclusion; the remaining papers were found in table 4 .

\section{Comment}

While two studies addressed the diagnostic question alone, no studies at all could be found regarding the usefulness of diagnostic aspiration in improving outcome. The sensitivity of white cell analysis is just too low for use as a 